困難な場合があるにとてでわれわれ仙，Sagittal section を含めた Triplane CT の有用性について検討を行った.

〔方法] Triplane CT の各撮影法の描出能, さらに, Coronal, Sagittal sectionの角度のちがいによる描出能 について, 比較, 検討した。

〔結果】 positioning としては，Coronal では $70^{\circ}$ 以下 Sagittal では $50^{\circ}$ 以上が望ましく，スライド厚さ，スライ ス間隔は，1.5 mm が最適であった。また，Triplane CT を用いるととで，微小下玨体腫湯の診断能は何上し た。

\section{CT による骨塩量測定の基礎的検討}

産業医科大学病院放射線部 井口政伸

骨相当物質としてポリエチレンチューブ（CT 值一8） に種々の濃度のガストログラフィン水溶液を封人し, 水 ファントム内でスキャンした．濃度に対する CT 值の直 線性は，良好であった，被写体サイズ，コンボリューシ ヨンフィルタにより CT 傎は変化し, 濃度が高いほど差 が大きくなった・腹部サイズのファントム内では骨ファ ントムの位置依存性は 2SD の範团にあった．高财収体 の辽縁部では，アンダーシュート，オーバーシュートが 生じ, 吸收差が大きいほじ強い。臨床に関しては，スキ ヤン部位と ROI の設定が閣題となり，CT 值の経時的 安定性も含めて，検討功必要と思われる。

\section{6. 当院における CT 装置のダウンタイム}

琉球大学医学部附属病院放射線部

○島崎順之・仲宗根定芳 真栄城守侯・仲間克己

当院に拐いて CT 装置 2 台稼動しているが過去 3 年半 のダウンタイムと故障内容, 故障回数を日誌, 台艮, メ 一カー側の作業報告等より求めて見ると第 2 世代 114 時 間でダウンタイム率 $2.7 \%$ ，第 3 世代204時間，ダウンタ イム率 $5.4 \%$ になる．故障内容は両装置共 CPU 系が 62 \%以上占めていて，故障回数では第 2 世代が多いがダウ ンタイムは短い，第 3 世代では高压系に要因があった。 九大馬場氏の資料「CT 装置の保守について」と比較し て，ほとんど差は見られず装置間によるバラッキがある。 沖縄の場合，海を隔てているハンディはあるにしても地 元メーカ一の協力がスムーズに行なわれている結果だ上 思われる。

\section{CT 装置の contrast-detail-dose 曲線による性能評} 価

健和総合病院放射線科

○村上美枝子・真野勇夫・堀永敏克 㻕 健司・岩村俊信・原田宇一
森山俊明

rCT 性能委員会」第 2 针告に基づいた項目とCohen が提起した Contrast-detail-Dose 曲線について調べた。

評価は，日常使用している Headの撮影条件について 行なった。

結論は，装置Cが線量效率が一番良かった。

装置 $\mathrm{A} \subset \mathrm{D}$ は，同等の線量効率であった。

48. CT 用 $\mathrm{X}$ 線管の劣化について（第 2 報）

九州大学医学部附属病院放射線部

○中村泰彦・馬埸 仁·安河内港輔 深野鿆一・田中順一・松尾文義

X線管の劣化を知る方法いろいろとあるが，今回陽極 の回転状態走知る方法について，2〜30実験を行なった ので報告する。

(1)コールドでの陽極の回転周波数および停止時間はほ とんど変化しない。

(2)エージング後 1 回毎の回転停止時間は 2 回目までは 長くなり 3 回目以後は一定となる。

(3)スキャン後の回転周波数を 6 時間測定すると，スキ ヤン後 5 分で小さくなり 3 時間には再び一定の值にもど る.

(4)スキャン後の司転停止時間は，時閒の経過とともに 短くなっていく。

以上の結果に基づきてれからも原因を追求して行きた ().

\section{座長集約}

この演題群では，CT に関するもの6 題が発表され， その内容は，撮影法，装置の性能評価，保守管理などの 全般にわたり，しかむ充実しており，日常の業務を行な う上で大いに参考になる報告であった，演者の方々の効 力と研讃に敬意を表したい.

演題43では，胆のうの検索に際し，エコーでは診断の 困難な症例について，造影剤を用いた CT 検查を行なう ことが確実診断に有用であるとし，またその撮影手技に ついても具体的な報告がなされ，即，日常業務に役立つ あのと思われる。

演題44では, 下垂体腫湯の CT 撮影法について, Coronal では $70^{\circ}$ 以上, Sagittal では $50^{\circ}$ 以上の角度が得 られれば彰断に有用であると具体的なデータを示しての 報告がなされ，有意義であった。

演題45では，CT による骨塭量測定を臨床に供する場 合，特に (1)体外加のアーチファクト (2)パーシャル ボリューム効果 (3) CT 值の直線性と再現性（4) 寸法依 存性（5)位置依存性（6)エッヂ効果など多くの問題があ 